\title{
AN HISTORIC ACCOUNT OF THE ORIGIN OF THE THOMPSON ART COLLECTION IN PERU, INDIANA AND ITS EDUCATIONAL USES
}

\section{Paul Engle}

I had the pleasure of teaching art at Peru High School in Peru, Indiana in the early 1970s and was given the responsibility of caring for one of the most valuable art collections owned by a school corporation and housed in a high school in this country. The Thompson collection consists of approximately one hundred original paintings, prints, and drawings by both American and European artists dating back to the French Impressionist era. Also included in the collection are many fine examples of Chinese pottery and figurines. Peru High School was a new facility and a gallery to house the collection was built adjacent to the art classrooms. Students either worked in the gallery or I brought the art work into the classroom where I used examples in my daily teaching.

While most art educators realize the value of exposing students to original art work, how many make it a priority to do this regularly or with strong educational objectives in mind? When students are methodically introduced to original fine art they learn more about both the appreciation and the making of art. They have models to learn from that are far superior to reproductions or slides. When students use original works of art as sources for their art work they learn to value the works of art and artists' planning. Close observation is valuable with original art whereas detail is diminished in reproductions. Students are likely to become interested in art in its context of history and culture when they are exposed to original work. When art is viewed as a reproduction it is hardly ever valued as more than an impersonal picture, but when original art is available to the student in full scale, color, and texture it becomes something "real" and valuable to the student. Of course it is not always easy to provide this experience with original works of art but there are means to accomplish it.

Through use of original art in the classroom, my students became literate about art. They identified medium, discussed subject, technique and periods of art and artists. They enjoyed placing a work in its context in history and many developed a hunger for seeing works of art and making art. Students developed high level skills of intelligently interpreting and criticizing works of art. They copied sections of paintings by imitating brush strokes and color and then compared their own works to the works in the collection. When shown slides or films, the students noted inaccuracies in color in the slide reproduction and asked about the scale of the piece or the artist's technique. The educational value of the availability of this collection was partly responsible for a restructuring of the Peru art program. More art classes were added as was a special program that served as a college or career preparatory course. Senior students were allowed to work three to four hours a day on problems of art, most of which were spawned by studying the works of the 
collection.

Only after I left Peru High School did I fully realize how important that collection was to my students and how it supplemented my teaching efforts. Original art in public schools should be used much more than it is at present. I wanted to learn more about the history of the Thompson Art Collection in Peru, Indiana and its educational uses and perhaps such knowledge also could enlighten art educators and administrators interested in procuring original works of art for educational purposes.

I began a standard historical approach to my inquiry by reading old news articles and other printed matter found primarily in Peru and Indianapolis. $\mathrm{I}$ also conducted a series of informal interviews with people who had knowledge of the collection's origin and uses. ${ }^{1}$ My primary source of information was Wayne Taylor, my predecessor as art teacher at Peru High School. Taylor was the city art director for nearly thirty years and he is now retired and lives in Florida. An accomplished watercolorist and draftsman, he still is actively painting and showing his work in Florida galleries.

I was aware that most of the Thompson Art Collection was donated by G. David Thompson. I did not realize how interesting a man Thompson was until I interviewed Taylor, a close friend of Thompson. Thompson was reared in Peru, Indiana during the early 1900s, and he was a student of average ability who had difficulty attending to school tasks. Only the presence of his favorite teacher, John Whittenberger, helped him remain in school.

According to Taylor, as a boy Thompson became interested in art. Taylor related an interesting anecdote which indicates a possible stimulus for Thompson's appreciation of art (Note 1). An itinerate artist in Peru known only by the name of "Wink the Wizard" sat in the front window of Singer's Dry Goods Store and drew pictures. Patrons of Singer's were awarded coupons which could be used toward the purchase of one of "Wink's" drawings. Thompson spent his Saturdays as a boy sitting outside the door of Singer's convicning patrons to give him their coupons. This same fascination Thompson had in collecting artifacts as a young boy extended into his adult life. Thompson developed an uncanny appreciation for good design and began collecting paintings of midwest regional artists as a young adult. As a man, Thompson became a top executive in the Pittsburg steel industry and served on the board of directors of several major companies. In Pittsburg. Thompson collected antiques of early American vintage and American and European original art which contributed to a fine and valuable art collection.

In 1946, when Taylor moved to Peru to teach art in the public schools, he met Thompson. Taylor related,

When I came to Peru, I noticed that several paintings were hanging in the halls of Peru High School. Several of them I recognized as (works of) Brown County artists such as Will Vauter and Dale Bessire. Most of the paintings were so dirty one could hardly make out the images. I decided that I would spend my Thanksgiving vacation repairing some frames and cleaning some of the paintings. It took me the 
rest of the school year to repair and clean them. That first summer Mr. Thompson came to town, he saw what I had been doing and asked to meet me. He was impressed because he had given eight paintings to the school in 1938 in memory of his favorite teacher, John Whittenberger, and until now no one had shown an interest in or had maintained the paintings. It was during our first meeting that Thompson told me he would give more paintings to the school if I planned to stay in Peru (Note 2).

Taylor developed a close relationship with Thompson and visited him frequently in his Pittsburg home. Taylor often returned to Peru with art treasures. Many fine pieces of American and European impressionist paintings, drawings, and prints were added to an already awesome Peru collection. Artists such as Roualt, Predergast, Sloan, Davies, and Picasso, to name only a few, were represented. These works were donated with the understanding that they be displayed and used for public appreciation and education. An example of Thompson's good intentions became apparent when he visited a ceramic workshop which Taylor taught for the community's adults. After observing several sessions, Thompson asked Taylor, "How would you like a few pieces of Oriental pottery to show your classes?" Of course Taylor thought it would be a great stimulus for his class to see such original works. About ten days after this offer, two wooden crates arrived containing 48 pieces of Chinese pottery dating from the Pre-Han Dynasty to the Ming Dynasty. Thompson continued to add to the Peru collection until his death in June 1965.

Through the friendship that Taylor developed with Thompson, Peru now has a handsome and valuable collection. Taylor's goal was to assure that the collection would be used educationally and I used it in much the same manner as he did. It was not unusual to see in one of our student's paintings of a still life a piece of Ming, Sung, or Tang Dynasty pottery. To allow more than Peru students to benefit from this collection, Taylor devised a program that allowed parts of the collection to travel from one Indiana community to another.

When I became Taylor's replacement as an art teacher in Peru in 1973, I recognized the excellent teacher he was and what a well developed program he had built. I also recognized that the Thompson art collection played an important role in Taylor's teaching and in motivating students to become excellent art students. The program continued to grow during my tenure at Peru High School and Taylor and I boast of having many former students who now work in art related professions. While the value placed on art in Peru appears greater than that of other small midwestern towns, it also has greater artistic stimulus than most. Our students' successes are attributable in no small way to the fact that we had quality original art in our environment every day. Art students do not, and cannot, create in a vacuum and the art work around them stimulated seemingly unlimited ideas and helped them to set high personal goals as well as to appreciate original art works.

Sadly, after I left Peru in 1976 there were no teachers interested in taking responsibility for the collection. With its growing value, administrators decided to lock it away and only show portions during special occasions such as plays at the high school. Some of my former students and other community members, 
however, maintained an interest in the collection and formed a city arts council to manage the works. Through a fund drive conducted in Peru and a grant from the State Arts Commission restoration and maintenance of the pieces now are assured. Presently there is discussion of selling several pieces to finance the construction of a museum with proper security. 2 Due to lack of appropriate exhibition space the pottery collection is on semi-permanent loan to the Indianapolis Art Museum.

While the steps taken to protect and maintain the collection are important, it was Thompson's wish that it be used especially for its educational value and admired for its beauty and historical value. According to several sources in Peru, unfortunately, the works of art are no longer used as teaching aids in the art classrooms. 3

Perhaps, the establishment of the teacher as curator plays an important role if programs like Peru's are to survive. As mentioned earlier, teachers and administrators must be active in seeking original art and understanding of the value of exposing students to works of art. Every community may not have as fine a collection as Peru, but if art educators and administrators search hard enough and inquire into museum and private collections, they are likely to find those who are willing to loan or donate works to art programs so that more people can be exposed to works of art as Taylor did with the Peru collection. There are also artists in every state who are willing to visit schools with their art or even lend some pieces on a temporary basis. Art clubs can purchase several paintings with money raised from selling their own art or from other activities that can be donated to school collections. Purchased works do not have to be old master works to be useful; works of regional artists sometimes can be purchased inexpensively and can be used for educational purposes.

There are other schools with unique collections of art. Through inquiry into the history and uses of these collections new information can be gathered to encourage art teachers to use original works of art in iheir teaching. Perhaps original art in the classroom will become a new and stimulating way for students to look at and talk about art as well as to appreciate and create their own art work.

\section{FOOTNOTES}

1. The information contained in this paper was obtained from telephone interviews, personal conversations and letter correspondence with a number of individuals during the period from May 1983 to September 1985. Grateful acknowledgement to Mina Bobel, Steve Grate, J. R. Sims and Wayne Taylor and others who wished to remain anonymous for their time and willingness to add to my existing knowledge of the subject and in keeping me on track by suggesting sources of information.

2. This information was obtained from a source who has asked to remain anonymous.

3. Same as footnote 2 . 


\section{REFERENCE NOTES}

1. Letter from Wayne Taylor to Paul Engle, May 8, 1985.

2. Phone conversation with Wayne Taylor March 14, 1985. 